REsumo

Este texto é resultado de uma pesquisa sobre o uso do espaco potencial de criatividade em crianças que vivem situa-

ção de privação e de abandono, considerando suas condições de sobrevivência na comunidade a que pertencem.

$O$ estudo aponta que as crianças expressam-se de modo criativo e preservam sua capacidade de reflexão no confronto com as situações do cotidiano, mesmo quando a realidade do seu grupo cultural for desafiadora e com obstáculos a enfrentar. A compreensão dos elementos empiricos investigados na realidade buscou apoio na teoria de Winnicott, especialmente nas relações com o espaço potencial de criatividade.

Descritores: relação mãebebê; espaço potencial; criatividade; subjetividade

\section{O ESPAÇO POTENCIAL DE CRIATIVIDADE EM CRIANÇAS QUE EXPERIMENTAM SITUAÇÕES DE PRIVAÇÃO}

\author{
Noeli Reck Masgi
}

Esta pesquisa ${ }^{1}$ foi realizada em uma comunidade de moradores na periferia urbana da cidade de Porto Alegre para estudar a forma como as crianças enfrentam as situações no cotidiano de suas vidas, marcado pelo desemprego dos pais, abandono, e pelos precários recursos destinados à sobrevivência pessoal. O estudo investigou em espaços formais, vivenciados no Centro Comunitário, e não formais, junto às famílias, as relações que as crianças estabelecem entre os pares, as alternativas propostas por elas nos momentos de frustração ocasionada pelo não atendimento às suas demandas.

$\mathrm{O}$ interesse pelo estudo surgiu a partir da escuta atenta às dificuldades freqüentemente verbaliza-

Professora da Pontifícia Universidade Católica do Rio Grande do Sul (PUCRS) e do Centro Universitário Ritter dos Reis, Porto Alegre. 
das pelos educadores de séries iniciais que se encontram em formação na universidade e que manifestam resistência para conviver com a impulsividade das crianças, bem como com a transgressão às regras construídas pelo grupo.

A problemática da carência da lei como instituinte do desejo tem acompanhado o depoimento dos professores, respondendo eles também com sentimentos de impotência diante das frustrações, conflitos e desafios, próprios do processo de aprendizagem dos seus alunos. As crianças trazem, desde a sua origem, um movimento próprio para falar de suas necessidades e pôr em ação os seus projetos. Para tanto, elas precisam de uma escuta diferenciada como a psicanálise tem. A escola e os professores expressam, na maioria das vezes, preocupação em compreender essas crianças; o que fazem, em geral, preservando-se e preservando o próprio projeto de trabalho: é a alienação do processo de aquisição do conhecimento.

A pesquisa centralizou a investigação sobre as crianças que foram excessivamente privadas do atendimento nas necessidades básicas como: cuidados com a saúde, alimentação, repouso, higiene, ou que sofreram um abandono ou trauma quando pequenas.

Para sustentar a idéia de subjetividade e dos modos de criar e inventar na criança, o espaço potencial teorizado por Winnicott (1975a) foi analisado e utilizado como recurso para a investigação teórica e empírica desta pesquisa. Servindo-nos desse referencial teórico, foi investigada a forma como as crianças inventam suas histórias e levam uma vida de relação e de inclusão social com os pares. A compreensão do modo como as crianças operam sobre a realidade e respondem às solicitações que lhes são propostas pode indicar caminhos para o professor flexibilizar sua ação docente com vistas ao desenvolvimento do processo simbólico.

Em sua redação, o texto apresenta subtítulos com elementos sobre a constituição psíquica do sujeito e do espaço potencial a partir da concepção psicanalítica de Winnicott. Em um segundo momento, apresenta os procedimentos utilizados na pesquisa e, a seguir, explicita as relações entre os moradores da comunidade, seus valores e o modo de vida das famílias nas quais foi realizada a pesquisa. Para finalizar, sugere algumas reflexões sobre possibilidades de intervenção pedagógica a partir do estudo realizado.

\section{Espaço potencial: a origem da criatividade}

O espaço potencial ${ }^{2}$, tema que, segundo Ogden (1995), sugere ser mais explorado na obra de Winnicott, refere-se a uma área em 
que se desenvolve a criatividade, o brinquedo, a imaginação e o jogo. Trata-se de um espaço em que as pessoas se expressam e anunciam a localização do seu brincar, embora nem sempre essa área esteja tão disponível, uma vez que ela se constitui no momento da separação entre o bebê e a mãe suficientemente boa. Uma exploração teórica na obra de Winnicott situará o espaço potencial e as relações com o processo de criatividade, bem como suas diversas formas de manifestação.

Para Winnicott (1982a), existem fases do desenvolvimento psíquico em que o sujeito transita de uma situação de dependência absoluta para uma situação de relativa independência. O crescimento, para esse autor, é visto como um momento de maturidade, uma condição em que o sujeito não coloca em risco a espontaneidade pessoal. "A independência nunca é absoluta. O indivíduo normal não se torna isolado, mas se torna relacionado ao ambiente de um modo que se pode dizer serem o indivíduo e o ambiente interdependentes" (Winnicott, 1982a, p. 80).

No período da dependência absoluta, o ambiente favorável possibilita o desenvolvimento do processo de maturação que está em potencial na criança. $\mathrm{O}$ ambiente, através dos cuidados maternos dispensados à criança, garante-lhe a sobrevivência. Mais tarde, vem o pai e os demais elementos da família. Todo o processo de adaptação da mãe e demais pessoas do ambiente para com a criança começa gradativamente a ceder espaço, para que a criança possa solicitar o que lhe falta, esperneando ou até chorando. Para Winnicott, esse momento também coincide com o retorno da mãe às suas atividades.

No período da dependência relativa, há uma possibilidade cada vez maior por parte da criança de esperar alguma coisa diante de alguma excitação, ruído ou ameaça do ambiente. Pela primeira vez, e em função da própria necessidade de esperar, o bebê se reconhece dependente. Não há somente um Eu; existem também outros elementos na cultura. Nesse período, há um entendimento de que a mãe é necessária e a criança faz uso disso. Aos poucos a criança vai lidando com a perda, e os fatores ambientais podem exercer importantes papéis, tais como substituir a mãe, dando um suporte necessário à convivência com a falta.

No período em que a criança vive a fase de conquista da independência, a ampliação dos grupos e dos círculos de amizade vai se tornando uma realidade, uma vez que ela se torna cada vez mais autônoma e diferenciada, embora a independência completa nunca seja atingida. Há, nesse percurso de crescimento da dependência rumo à independência, momentos de imitação e estabelecimento de uma identidade para dar continuidade à vida pessoal.

160 Estilos da Clínica, 2007, Vol. XII, nº 22, 158-175 
$\mathrm{Na}$ linguagem de Winnicott, a origem da criatividade e da expressão simbólica ocorre quando a criança inicia o processo de separação e de reencontro com a mãe. Não se trata de um espaço anatômico, mas de uma vivência, em que o sujeito experimenta sentimentos ambivalentes entre fantasiar e perceber a realidade, sentir-se unido e, ao mesmo tempo, separado, sentir-se só e ao mesmo tempo acompanhado. Um espaço em que prevalece a dialética da afirmação e da negação, o lugar da experiência cultural em que a criatividade se faz presente em todos os sentidos.

Esse processo ocorre, porque a mãe suficientemente boa se oferece para ficar no lugar imaginado pelo bebê, criado como algo confortável para sobreviver ao sofrimento causado pelas necessidades. Mais tarde, o objeto criado continua presente, mas há uma desadaptação dele frente ao desejo da criança. Winnicott nos diz que nessa presença, que também está ausente à demanda, o sujeito cria formas alternativas de experienciar a falta. Nesse caso, a subjetividade institui-se nos graus de consciência entre o ter e o seu inverso; o Eu só pode ser constituído a partir do Outro; a individualidade é originária da alteridade. Entre ser um e ao mesmo tempo dois, entre ser idêntico e ser diferente, há necessidade de buscar alternativas.

A partir da experiência vivenciada com e pelo outro, a criança encontra alternativas que substituem o objeto ausente, embora não tragam o objeto em cena. Assim como a mãe cria o bebê e o bebê cria a mãe, o processo dialético inconsciente instala a subjetividade a partir da semelhança e da diferença. Portanto, subjetividade e intersubjetividade se constituem na medida em que uma não existe sem a outra. Os teóricos da psicanálise que dão destaque às relações objetais, como Aulagnier (1979), Lacan (1988), Winnicott (1982a), enfatizam o lugar privilegiado da mãe como norteadora e demarcadora da existência do bebê e os mecanismos primitivos emanados das fantasias arcaicas e da angústia de aniquilamento.

A identificação da mãe com as necessidades do filho e o acolhimento dos elementos que lhes são projetados dá origem a um espaço "entre" os dois; é o espaço da intersubjetividade. Esse processo também é gerador de ansiedade, uma vez que o bebê vai se constituindo nesse espaço como um e como dois, ou seja, como um eu e um não eu: esta descentração é uma conquista realizada por ambas as partes, momento em que mãe e filho se constituem. Segundo Winnicott (1993), é nesse espaço de enriquecimento mútuo que se origina a criação, a invenção e também a simbolização com todos os desdobramentos que elas possam conter e que mais tarde se poderá nomear o espaço transicional.

Quando Winnicott concebeu a idéia de objeto transicional, fez referência a uma forma de relação em que o bebê está ao mesmo tempo conectado e separado. Através dos objetos transicionais, o bebê cria uma realidade por meio da qual ele pode se beneficiar nos momentos de dificuldade, de desejo de companhia e 
de conforto. As funções exercidas pela mãe oportunizam a sustentação para o desenvolvimento do psiquismo na criança. Ela proporciona o bolding $^{3}$, num momento de extrema imaturidade do bebê, que nessa fase experimenta as sensações de toque e de olhar situando um "eu" e um "não eu". Essa sensibilidade desperta processos secundários como a inteligência e a função simbólica.

A intersubjetividade só é possível ao bebê quando há uma vivência de relação entre dois; em que um cria o outro, mas, ao mesmo tempo, permite que cada um seja ele mesmo. A mãe faz o percurso inicial ao bebê para, mais tarde, ele sentir-se independente. Quando o bebê reconhece a sua independência, ele destruiu a mãe como um objeto inventado por ele, mas trata-se de uma destruição criativa. Há reconhecimento da mãe como um sujeito separado, emerge também a subjetividade da criança que, ao mesmo tempo, também se altera em virtude desse encontro não acabado e sempre sustentado pela dialética da afirmação e da negação. Se, para Freud, a subjetividade se constitui na dinâmica entre inconsciente e consciente, em função dos elementos reprimidos porque não tolerados pela consciência, para Winnicott ela se dá no espaço "entre" interno e externo, ilusão e desilusão, a partir das primeiras relações entre a mãe e o bebê.

As fantasias iniciais predominantemente onipotentes por parte da criança projetam na mãe fantasias de completude e de indestrutibilidade. Essas fantasias cedem lugar à realidade com 
o reconhecimento da mãe externa, que nutre e que frustra porque se mostra incompleta e suficientemente boa. Para que haja essa construção, é necessário que a mãe se disponibilize: primeiro, para fortalecer no bebê a fantasia de um ser completo, que tudo pode e permite; mais tarde, ela também se autoriza a destruir essas fantasias de onipotência para entrar o espaço da falta e da desilusão, da criatividade e da simbolização.

$\mathrm{Na}$ criatividade existem três situações que se complementam e superpõem: o sujeito que gera a experiência, o objeto do desejo que não se encontra à disposição e o elemento que transita para substituir a falta, ou seja, os próprios símbolos. A função simbólica é a condição que distingue o homem de outros seres da natureza.

\section{Procedimentos da pesquisa}

A abordagem da pesquisa, de caráter qualitativo, utilizou como instrumentos para coleta de dados observações, entrevistas, grupo focal, narrativas infantis e brinquedo. Os instrumentos, dirigidos aos pais, monitores, líderes comunitários e às próprias crianças, traziam no seu roteiro questões para investigar o modo de relação dos moradores; suas rotinas; quem exercia as funções materna e paterna; como as crianças brincavam e quais as suas reações diante das restrições, dos limites impostos ou dos conflitos a serem enfrentados no cotidiano das relações.

O estudo aproximado ao tipo etnográfico foi utilizado para conhecer os traços culturais das crianças e de suas famílias. Observou-se intensamente a vida da comunidade, registrando o mapa de localização das pessoas, o relato do que normalmente faziam nas suas atividades diárias, como interagiam, o que expressavam e como se organizavam diante das dificuldades. Esse método possibilitou permanecer em companhia de pessoas e de grupos, facilitando o registro de comportamentos, tendo presente o foco pretendido para estudo.

Foram entrevistadas pessoas da comunidade, coletados seus depoimentos em festas, em momentos de trabalho e de lazer. Os depoimentos permitiram também coletar dados sobre a regularidade dos comportamentos, sobre as expressões e linguagem dos sujeitos tanto individualmente, quanto em situação de grupo. As crianças eram observadas junto às rotinas da família e no centro comunitário onde eram realizadas oficinas de pintura, artesanato, leitura, dança e demais atividades coordenadas pelos monitores de grupo. $\mathrm{O}$ universo da pesquisa envolveu o acompanhamento de dezoito crianças em fase de escolaridade inicial e que freqüentavam 
diariamente o centro comunitário, no horário do dia em que não se encontravam na escola.

Para interpretação e análise dos dados, tomaram-se como referência o estudo e a construção de dois casos com planos de análise delineados a partir das primeiras observações empíricas. Foi utilizada uma metodologia de investigação intensa e extensa de dois sujeitos e de suas famílias a respeito das suas expressões, das formas de lidar com a realidade e demais comportamentos grupais. $\mathrm{O}$ estudo de caso desenvolvido nesta pesquisa permitiu não somente preservar o que é singular na história dos sujeitos, como também contemplar as especificidades mais genéricas do grupo e da comunidade.

A pesquisa buscou na psicanálise a fundamentação para analisar os elementos conceituais e empíricos do objeto proposto para investigação referente à função paterna e suas formas de manifestação no simbólico, bem como o uso do espaço potencial como expressão da criatividade.

A análise foi revelando que as manifestações dos moradores, quando tomadas isoladamente ou em seu conjunto, iam se repetindo em alguns aspectos. Por exemplo: no estudo promovido pela assistente social para verificar se as condições sócio-econômicas das famílias justificam a necessidade de auxílio financeiro para subsistência das crianças, as mães não revelavam a ausência e a omissão dos companheiros como dificuldade a ser considerada. A figura paterna era preservada em alguns casos ou denegada em outros, no depoimento das mães, em situações de grupo, nas visitas às famílias, na hora de negociar pagamento da creche ou mensalidade do centro comunitário. Por outro lado, as dificuldades para enfrentar a vida cuidando sozinhas dos filhos manifestavam-se através de queixas sobre doenças e falta de atendimento nos postos de saúde.

O grupo focal permitiu a obtenção de dados de natureza qualitativa a partir de sessões em grupo em que dez mulheres, compartilhando alguns traços comuns, discutiam aspectos de um tema sugerido. Essa técnica possibilitou a identificação e o levantamento de opiniões que refletiam o grupo em um tempo relativamente curto, otimizado pelo confronto de idéias sobre as dificuldades no cotidiano de suas vidas.

A narrativa infantil foi utilizada como um dos recursos para investigar como as crianças expressavam e regulavam os seus desejos e como evocavam suas experiências pessoais vivenciadas especialmente com os pais. Considerou-se narrativa infantil para este estudo toda história contada, inventada ou dramatizada pelas crianças em situações dirigidas e espontâneas, individualmente e em situações de grupo. Este recurso de investigação buscou a forma do discurso oral das crianças com a utilização de alguns recursos materiais como materiais para teatro, fantoches e livros de histórias.

O brinquedo foi observado no cotidiano das crianças e em todas as formas de expressão, incluindo as narrativas. $\mathrm{O}$ espaço potencial de criação foi investigado através dos mecanismos psicodinâmicos implicados nas construções verbais e demais for- 
mas de expressar os conflitos gerados em cada situação observada. Para analisar o uso do espaço potencial e a operância do simbólico, foram levantados elementos conceituais de Winnicott, que, fundamentados na leitura psicanalítica, possibilitaram a análise dos dados empíricos.

Ogden (1995, p. 79), inspirado nas idéias de Winnicott, partiu da experiência clínica para incluir as seguintes hipóteses sobre a patologia do espaço potencial: o rompimento prematuro na unidade mãebebê, a hipersensibilidade constitucional do bebê e o trauma resultante desde a doença física até a morte de um dos genitores ou de um familiar, podendo ocasionar fracasso em criar ou manter a dialética do espaço potencial.

O presente trabalho propôs-se a investigar se, mesmo com as experiências de privação no desenvolvimento inicial, em situações de abandono dos pais ou de separação precoce dos cuidadores, as crianças encontram formas de manifestar a subjetividade, mantendo a dialética do espaço potencial. Uma aproximação com esses princípios teóricos possibilitou o levantamento de categorias de observação empírica, indicadoras da manutenção da dialética do espaço potencial.

Foram levantadas quatro categorias de observação empírica para registrar situações em que o processo dialético se fazia presente: a flexibilidade, observada pela tolerância às frustrações nos momentos de perda e de espera; a discriminação, observada pela capacidade de ouvir o outro, estabelecer diálogo e perceber o que ocorria no meio ambiente; a capacidade reflexiva: observada pela forma de tomar decisões considerando os fatores presentes na situação e a percepção da realidade: observada a partir do reconhecimento das possíveis conseqüências da própria ação diante do Outro. $\mathrm{Na}$ análise final, foram considerados a regularidade $\mathrm{e}$ o modo de apresentação das declarações e expressões dos sujeitos investigados. Além disso, foram estabelecidas as interconexões entre os dados empíricos e os princípios teóricos levantados.

\section{A comunidade investigada: um modo de vida}

Uma comunidade de moradores vive um cotidiano realçado por momentos de intenso prazer e desprazer. Assim passam os dias de suas vidas crianças acompanhadas ou não dos seus pais, convivendo com a falta de recursos materiais e a instigante luta para sobreviver em espaços físicos muito reduzidos. $\mathrm{O}$ mesmo não se pode dizer sobre o espaço no sentido psíquico; algumas práticas são exploradas de modo intensamente diversificado e criativo, com precários recursos disponíveis.

Para compreender o modo de vida desse grupo, seus valores e a cultura que predomina entre os seus moradores foram realizadas observações para acompanhar crianças e adultos em geral. A cultura referida a classes populares retoma a experiência da pesquisa de campo realizada por Maggi (2005), cujas visitas tor- 
naram possível um reconhecimento da identidade e das diferenças em relação à comunidade investigada. Brandão (1986) designa cultura um conjunto de estruturas de significado e de saber, permeadas por processos de comunicação. Esse tema é aqui tratado tendo como referência essa concepção, ou seja, compreender o modo de vida dos sujeitos, os papéis e os espaços designados aos pais e demais representantes do grupo familiar, como também a forma de articulação das funções que a todos estão atribuídas dentro dos grupos; grupos que trazem na sua formação alguns condicionantes e que, no contato com o ambiente social imediato, operam dialeticamente através do processo de socialização.

Essa concepção auxilia a compreensão dos elementos apontados pela psicanálise a respeito da história trazida pela criança no seu desenvolvimento inicial. O sujeito, como portador inalienável dos traços culturais, revela o que lhe marca o cotidiano das relações, sem, no entanto, de acordo com Maggi (2002), abandonar as marcas originárias que o constituíram psiquicamente.

A comunidade investigada caracteriza-se pela concentração de moradias de população de baixa renda, carentes dos serviços básicos essenciais e que sofre os efeitos de longos deslocamentos para o trabalho, o consumo e o lazer. Altas taxas de crescimento demográfico fortalecem as demandas básicas para a sobrevivência pessoal e familiar, acenando para a urgência no atendimento preventivo à saúde, à alimentação e ao modo de relação junto às crianças que ocupam um número significativo dessa população. Os adultos raramente têm uma regularidade de trabalho que lhes possibilite sistematizar horários, prever orçamento ou ter perspectivas de uma ação futura. Nessas condições, prevalecem as tomadas de ação imediata num esforço de encontrar alternativas rápidas diante da busca de sobrevivência pessoal e familiar.

Uma superpopulação de famílias em espaços reduzidos, com uma grande concentração de crianças de todas as idades, incluindo adolescentes, utiliza a rua como espaço de brinquedo ou busca no centro comunitário uma oportunidade para praticar oficinas, jogos e outros tipos de recreação. No decorrer do processo de investigação, o olhar e a escuta estiveram atentos ao que ocorria tanto do lado do investigador como do lado do investigado, para manter a distância necessária e desenvolver uma análise menos comprometida com questões de subjetividade pessoal.

Como diz Diógenes (1998, p.17), "a nossa subjetividade, essa eterna desconhecida, se desvenda para nós, em todo o processo de investigação, como matéria-prima dos esforços de decodificação das representações do outro, do desconhecido e como argila para que se possa moldar um mapa possível de interpretação de expe-

166 Estilos da Clínica, 2007, Vol. XII, nº 22, 158-175 
riências estrangeiras e, muitas vezes, exiladas da nossa própria compreensão".

O impacto provocado pela diferença e por uma realidade estranha ao que se postula como o que é esperado para o desenvolvimento de uma criança intensificou a necessidade de pesquisar. Noções conceituais sustentadas pelas pesquisas sobre desenvolvimento infantil e que apontam para as reais necessidades de as crianças terem um atendimento regular e confiante feito pelos pais ou cuidadores, para que possam sobreviver e ingressar no mundo do conhecimento estiveram sob suspeita durante esta investigação empírica. Se por um lado havia inquietações, elas se tornavam elementos significativos para análise e confrontação com os elementos conceituais. O imaginário construído ao longo da história de trabalho e de formação foi sendo confrontado a cada momento em que o processo de investigação anunciava novos elementos. $\mathrm{O}$ modo como a criança experimenta e vivencia o processo de filiação e utiliza o espaço potencial de criatividade tornou-se elemento central para a reflexão neste estudo.

Crianças conseguem brincar, apesar da ausência de adultos para possibilitar a necessária sustentação às suas demandas. Brincam também sob condições de absoluta precariedade material. $\mathrm{O}$ afastamento dos pais causado pela morte ou abandono quando a criança vive seus primeiros anos de vida não impede que ela fale desses acontecimentos contando histórias, desenhando, dramatizando ou refletindo sobre o ocorrido. Enquanto a senhora avó se refaz do luto pela perda da filha com vinte e quatro anos, um entre os quatro netos que agora está órfão aconchega-se ao coelho de pelúcia e observa os espaços que antes eram ocupados pela mãe. Já não pode mais ser cuidado pelos pais, mas inventa um objeto de relação, simula um brinquedo para conviver com a inevitável falta da mãe. $\mathrm{Na}$ relação com a avó vivencia o processo simbólico de recuperação dos cuidados.

Um menino com sete anos, impedido pela mãe de encontrarse com o pai, chora desolado e ao mesmo tempo se refaz, enquanto brinca com o animal de estimação. É especialmente no brinquedo que crianças se refugiam e parecem entregar-se à imaginação, fazendo do animal de estimação o interlocutor, ou criando histórias que aliviam a ansiedade causada pela dor do abandono, da morte ou da separação.

A precariedade de recursos não é mencionada no cotidiano das famílias, e tudo é resolvido para aquele dia em função da necessidade que emerge. Crianças continuam brincando sem lamentar o objeto perdido ou buscando outras formas de recreação. A necessidade de recuperar a bola no pátio do vizinho é imediata- 
mente refeita, buscando um objeto substituto.

As crianças anunciam suas faltas através dos depoimentos, dos desenhos, das histórias contadas e dos brinquedos dramatizados. Enquanto inventam suas histórias, há uma representação de objetos ausentes na vida real, embora presentes nas cenas improvisadas, tais como: o coelho de pelúcia para elaborar o luto com a avó; o animal de estimação nas horas de desentendimento com a mãe; o desenho para falar de um pai ausente ou a busca de um brinquedo que substitui a bola perdida no pátio da casa ao lado.

Observo ainda que, não havendo espaços para brincar, as ruelas e os becos servem de esconderijo para a brincadeira de esconde-esconde, ou para montar o jogo de botão. Enquanto se entregam às cenas improvisadas com os recursos do jogo simbólico, as agressões físicas ou os comportamentos colocados em ato assumem um lugar secundário. A comunidade designada periferia urbana, local da investigação, é constituída de inúmeras pequenas vilas, contendo ruelas e becos com acessos que se bifurcam no seu interior, cuja assimetria faz com que as moradias se confundam entre vizinhos. Aparentemente, todos se conhecem. Uma pessoa que no quintal de outra casa estende as roupas no varal acena para cumprimentar. Mais adiante, em uma casa com dois pisos, duas crianças olham a rua através de pequena janela. Aguardam o retorno da mãe, que saiu para trabalhar e, não tendo onde deixá-las, resolveu mantê-las brincando em casa como medida de segurança.
Na comunidade, sempre há um parente ou um conhecido que repara as crianças. Isso nos lembra Dor (1991), quando fala do pai e de sua função em psicanálise. A função paterna pode ser exercida por um genitor, pelos pais da realidade, por um operador da cultura: vizinho, parente ou trabalho, que ocupe o lugar de um significante para substituir outro significante. O que importa naquele espaço é que sempre haverá um objeto, pessoa ou situação para estabelecer a ordem e o limite a fim de conter a ansiedade que emerge no enfrentamento com a realidade.

A comunidade investigada revela que as condições sociais e econômicas dos moradores são bastante precárias em relação aos bairros centrais da cidade em que moram as famílias de renda média ou alta. O desemprego e a baixa escolaridade dos moradores dificultam o acesso ao mercado de trabalho, empobrecendo cada vez mais as famílias que procuram os biscates e as atividades alternativas para sobrevivência. As famílias são constituídas de mães que cuidam dos filhos ou de avós cuidando dos netos, e as separações, assim como os recasamentos, são bastante freqüentes entre os casais. Em função do sofrimento causado pela miséria, pelas separações ou abandono pelos pais, as crianças investigadas revelam um apego exagerado aos cuidadores, como também defesas contra a experiência de frustração no cotidiano de suas vidas.

O uso do espaço potencial de criatividade está presente nas horas de brinquedo, quando as crianças simulam papéis, inventam personagens, 
desenham e contam histórias. Observa-se que está preservada na criança a possibilidade de operar no registro simbólico, na medida em que inventa situações que garantem uma realidade desejada. Com recursos do imaginário tudo se transforma e os atores passam a ocupar lugares que estariam impedidos nas cenas do real.

Ao observar uma mãe segurando o seu bebê, com meses apenas, percebe-se que dorme amparado nos braços e expressa muita tranqüilidade. Simbiose e onipotência é o que aparenta naquele momento. Vive a sua onipotência, isto é, fragilidade total. Vivência em total ilusão. Com base em Winnicott (1982b), não é difícil conectar-se com processo primário, narcisismo primário, estado de dependência absoluta, traços mnêmicos e egóicos, limiar de movimento no espaço transicional em que não existe um eu totalmente subjetivo e não há um objeto totalmente objetivo.

Esse bebê provavelmente não suportaria uma falha muito grande dos cuidados ambientais. Ele necessita estar abastecido de uma mãe totalmente boa, para, mais tarde, suportar pequenas frustrações, provocadas por uma mãe suficientemente boa. Assim teorizou Winnicott, a partir da clínica com crianças. Os registros de observações foram revelando que, mesmo com laços interrompidos entre pais e filhos, ainda resta uma possibilidade de as crianças utilizarem a criatividade, em situações de brinquedo ou de histórias inventadas.

Crianças abandonadas pelos pais logo após o nascimento, ou impedidas de conviver na mesma família com os irmãos em função da precariedade de recursos físicos, manifestam intensa demanda de atenção e dificuldade para vivenciar as separações, mesmo que momentâneas. No centro comunitário e em outros espaços da comunidade observaramse crianças expressando apego corporal intenso junto aos monitores e adultos mais familiarizados. Parecia necessário o toque, o contato, o olhar e a resposta imediata às muitas e insistentes inquietações. Segundo Winnicott (1975b), a falta de confiança anula o espaço, impede a busca, a criatividade e o pensamento, ou prejudica-o em parte. Essa situação em que o processo de pensamento era dificultado pela necessidade de gratificação imediata era rompido quando se anunciava uma brincadeira, a simulação de uma história, ou o relato de um acontecimento.

Entre os comportamentos observados, foram identificadas crianças que inventam alternativas no decorrer das brincadeiras e utilizam a linguagem simbólica para falar do que lhes falta. Para Winnicott (1975a, p. 142), "o espaço potencial entre o bebê e a mãe, entre a criança e a família, entre o indivíduo e a sociedade ou o mundo, depende da experiência que conduz à confiança. Pode ser visto como sagrado para o indivíduo, porque é aí que este experimenta o viver criativo".

\section{A intervenção pedagógica: algumas reflexões}

A saída da criança de casa e a entrada na escola é um marco no seu 
desenvolvimento, indicando a primeira grande ruptura da família para ingresso em um grupo mais amplo de pessoas com as quais vai constituindo as identificações. A criança traz marcas da cultura familiar instituídas a partir das relações que foram estabelecidas para a sua sobrevivência e que mais tarde transformam-se em representações de objetos internos; ela necessita do apoio dos adultos, pais e cuidadores, para que esse processo ocorra.

Ao falar das perdas precoces na infância como a morte dos genitores ou a desagregação familiar, Winnicott (1975c) faz referência à necessidade de alguma criança assumir prematuramente responsabilidades, com o risco de perder a espontaneidade, a capacidade de brincar e o impulso criativo despreocupado. A confiança que orienta a vida das crianças que foram destacadas como objeto desta investigação, mesmo sendo abandonadas por um dos genitores, não está na confirmação de que elas possam recuperarse dessa dor. A confiança está no crédito e sustentação - concedidos pelos cuidadores - de que elas são portadoras de um desejo e possuem um processo de continuidade de existência vital.

Buscando em Aulagnier (1979) um paralelo para as afirmações teóricas sobre a constituição psíquica do sujeito, identifica-se a necessidade de desejar não só a criança, mas pela criança. Da mesma forma, terão mais êxito em desempenhar esse papel tanto os pais na família, quanto os professores na escola, se estiverem inscritos na ordem simbólica. A capacidade da criança para suportar as faltas ou para expressar o desejo com recursos do simbólico necessita do suporte de um adulto capaz de acolhê-la tanto na sua dor como na sua onipotência.

Para trabalhar com crianças, é necessário compreender a história de suas vidas, o que as marcou, para ir ao encontro delas e estabelecer diferentes formas de interação. Buscar a criança no lugar em que ela se encontra fortalece a hipótese de que as marcas originadas por um olhar seguro e confiante no desenvolvimento inicial ajudam-na a organizar-se diante dos conflitos. Para se aproximar da história dessas crianças, na ação docente, o professor necessita revisar sua trajetória escolar, falar ou pensar sobre suas experiências e sua vida de relação.

A criatividade das crianças investigadas está presente na hora de ajudar o amigo a desvendar o mistério do jogo, como também na tolerância à frustração, percebida nos momentos em que são vencidas pelo opositor. Demonstram relativa aceitação no momento em que o ator da brincadeira necessita deslocar papéis e capacidade reflexiva quando, ao final de um jogo, reconhecem o vencedor. As narrativas inventadas carregam a dureza do cotidiano, mas há uma representação do amor e do ódio traduzidos na linguagem 
oral que aparece deslocada para um personagem. O oprimido da vida real transforma-se em opressor na história ou no teatro, dando a chance de realizar a justiça mediante um processo ordenado e de uma suposta convivência com o outro. Para Winnicott (1994, p. 50), "sem o brinquedo, a criança é incapaz de ver criativamente o mundo, e, em conseqüência disso, é arrojada de volta à submissão e a um senso de futilidade, ou à exploração de satisfações instintuais diretas".

Observa-se que, enquanto brincadeira, as crianças expressam a possibilidade de construir e reconstruir as imagens que povoam seus sonhos. As dificuldades se reduzem na hora de deslocamento para o jogo de faz-de-conta, em que as possibilidades de criação não têm limites. Se o personagem quase morre na história narrada, mais tarde sobrevive, porque alguém o acolheu. As situações limites são experimentadas com muita imaginação e possibilidades de retorno do objeto supostamente perdido. O uso do espaço potencial parece estar preservado, dando-lhes condições de viver criativamente as narrativas inventadas, concedendo vida aos personagens e transformando as suas dificuldades cotidianas em formas de relacionamento, tal como ocorre na vida real.

As intensas dificuldades para brincar e conviver entre os pares são mais freqüentes entre as crianças que se sentem ameaçadas ao enfrentar a realidade externa e têm experiências de relacionamento bastante restritas. Crianças para as quais "o mundo foi apresentado de maneira confusa crescem sem qualquer capacidade de ilusão de contato com a realidade externa; ou então esta sua capacidade é tão frágil, que facilmente se quebra num momento de frustração" (Winnicott, 1990, p.135).

A preferência pelas brincadeiras solitárias, o excesso de rivalidade e a dificuldade de contato com a realidade estão mais presentes em crianças que sofreram privações nos momentos precoces do desenvolvimento. Observa-se, no entanto, que no brinquedo há uma primazia de satisfação em dialogar com personagens e que satisfazem de alguma forma o que desejam. Compreender a história dessas crianças e o que marcou o seu desenvolvimento inicial torna-se uma preocupação instigante para desenvolver atividade pedagógica competente.

Mesmo havendo privação, abandono, precariedade de recursos para sobrevivência, o uso do espaço potencial em que se originam a criação e o brinquedo parece estar preservado ou com o uso parcial, dependendo das condições de cada sujeito. Após o término do brinquedo, observa-se dificuldade de operar no nível simbólico, prevalecendo expressões de atuação.

As crianças com capacidade para simbolizar têm acesso à imaginação e à criatividade próprias do ser humano. Entretanto, essa 
possibilidade torna-se efetiva quando ela já é capaz de se deparar com a realidade proporcionada pelo cuidador capaz de ser suficientemente bom, mesmo que essa realidade seja frustrante. Provocar o estado de falta suportável à criança, a fim de instalar nela o desejo de continuar buscando alternativas para as suas ações, só poderá ser desempenhado por uma pessoa que tenha vivido essa experiência.

Aulagnier (1991, 1979), Bleichmar (1994), Freud (1980), Lacan (1998), Nasio (1991), Ogden (1995) e Winnicott (1982b, 1982c), apontam elementos conceituais, com base em seus estudos, de que a presença da lei, ou de um terceiro representado pela função do pai na relação mãe-filho, possibilita ao sujeito sair da condição de natureza; possibilita ao sujeito expressar diretamente a energia pulsional para entrar na condição de um ser civilizado, ordenando as suas necessidades em função do grupo e da cultura à qual pertence. A ausência da função paterna ocasionada por um trauma ou pelo trágico rompimento da relação entre a mãe e o filho pode fragilizar o processo de simbolização.

Este referencial teórico possibilita novas reflexões, visto que as crianças investigadas, mesmo tendo sofrido perdas como abandono logo após o nascimento, desnutrição, morte de um dos pais ou de familiar próximo, separação judicial da família em razão de delitos cometidos, apresentam significativa capacidade criativa nos momentos de brinquedo livre e dirigido. À medida que as crianças brincam, constróem histórias e falam da própria história, passam a poder também assumir-se, junto aos pares, como um novo protagonista nas situações improvisadas pelo grupo.

Uma reflexão sobre o uso do espaço potencial permite observar como as crianças se locomovem através dos personagens criados bem como dos espaços a eles designados, atribuindo significados e estabelecendo relações de amor e de ódio como forma de falar das suas vidas. Dentro dessa perspectiva, observa-se que os sujeitos investigados expressam tolerância às frustrações, mesmo que de modo restrito, ou ainda relativizam os fatos e tomam posição diante de um conflito quando se faz necessário.

Através do brinquedo, das narrativas inventadas e, especialmente, da forma de se relacionar e de representar os objetos, personagens e situações em cada momento vivido, é possível refletir sobre a operância no processo de simbolização. Observase que os sujeitos deste estudo, embora privados da presença dos pais da realidade ou da invasiva presença da mãe, enquanto narram suas histórias e combinam situações de jogo conseguem discriminar os papéis, os lugares e as pessoas. Junto com esses elementos representados no brinquedo, os personagens são pensados no nível imaginário, ao mesmo tempo em que a expressividade do jogo simbólico faz-de-conta traz um diálogo em que se faz presente o reconhecimento do Outro.

Às crianças que foram privadas do espaço potencial para criar, imaginar ou inventar saídas diante do caos pulsional manifesto resta alguma esperança de que a escola como uma instância educacional possa de- 
limitar tanto o espaço geográfico quanto o espaço psíquico de criatividade com a presença de educadores generosos e firmes no que desejam de seus alunos.

É necessário destacar que os traumas no desenvolvimento inicial provocando dificuldades no processo de simbolização não estão restritos aos sujeitos que vivem em condições sócio-economicamente desfavoráveis. Como o desenvolvimento também está relacionado às condições psíquicas dos pais, o fator transgeracionalidade é elemento importante para a saúde psíquica do filho. Adultos responsáveis pela educação da criança, pais, avós ou demais cuidadores que tiverem vivido a experiência da função paterna e que respondem aos apelos libidinais e sociais com razoável capacidade de simbolização parecem conseguir exercer essa função de modo eficaz.

Por se tratar de um estudo metapsicológico, este trabalho exclui as relações de causa e efeito tais como pais ausentes e crianças com dificuldade para simbolizar, ou presença efetiva dos pais junto dos filhos e expressão da criatividade e do processo de simbolização diante das exigências impostas pela realidade.

É com base em alternativas pensadas, imaginadas, recriadas que a criança consegue ordenar seu desejo e fortalecer o espaço potencial de subjetividade. A idéia de cultura e de civilização traz no seu bojo a função paterna, ou seja, a presença acolhedora e delimitadora de adultos responsáveis pela educação da criança, capazes de conter a sua ansiedade. A pedagogia parece melhor cumprir a sua função quando o sujeito vivenciou uma castração simbólica relativamente bem sucedida. Uma criança que inicia a escolaridade, preservada a sua singularidade, necessita ser acolhida com limites e inserida nos códigos e valores sociais para sentir-se segura e verdadeiramente participante do seu projeto de vida e do grupo social mais amplo.

\footnotetext{
Abstract

THE POTENTIAL SPACE OF CREATIVITY IN CHILDREN WHO EXPERIENCE SITUATIONS OF PRIVATION

This text is the result of a research about the use of potential spaces of creativity by children who experience situations of privation and desertion. Consideration is taken with regard to the conditions under which these children live in the communities to which they belong. The study indicates that these children can express themselves in a creative way, preserving thus their ability for reflection when confronting everyday situations, even when the reality of their cultural group is challenging and presents obstacles to be faced. The comprehension of the empirical elements under investigation here found its ground in Winnicott's theory, especially in the relations with the potential spaces of creativity.

INDEX TERMS: mother-child relationship; potential space; creativity; subjectivity

\section{RESUMEN}

EL ESPACIO POTENCIAL DE CREATIVIDAD EN NIÑOS QUE VIVEN SITUACIONES DE PRIVACIÓN

Este texto es el resultado de una investigación acerca del uso del espacio potencial de creatividad en niños que viven situaciones de privación y de abandono. Es evidente que consideramos sus condiciones de supervivencia en la comunidad a la que pertenecen. El estudio señala que los niños se expresan de una manera creativa y conservan su capacidad reflexiva mientras se confrontan con las situaciones de la vida cotidiana, aunque la realidad de su grupo cultural sea desafiante y les presente obstáculos a franquear. La comprensión de los elementos empiricos investigados en la realidad ha encontrado soporte en la teoria de Winnicott, especialmente en las relaciones con el espacio potencial de creatividad.
} 
Palabras claves: relación madre-niño; espacio potencial; creatividad; subjetividad

\section{REFEREANCIAS BIBLIOGRÁFICAS}

Aulagnier, P. (1979). A Violência da interpretação (M. C. G. Pellegrino, trad.). Rio de Janeiro: Imago.

(1991). Observações sobre a estrutura psicótica. In Katz, C. S. (Org.). Psicose: Uma leitura psicanalitica (A. Senna et al., trad.). São Paulo: Escuta.

Bleichmar, S. (1994). A fundação do inconsciente (K. B. Behr, trad.). Porto Alegre, RS: Artes Médicas.

Brandão, C. R. (1986). A educação como cultura (2a ed.). São Paulo: Brasiliense.

Diógenes, G. (1998). Cartografias da cultura e da violência: Gangues, galeras e o movimento. Hip Hop. São Paulo: Annablume.

Dor, J. (1991). O pai e sua função em psicanálise (D. D. Estrada, trad.). Rio de Janeiro: Zahar.

Freud, S. (1980). Sobre o narcisismo: uma introdução. In S. Freud, Edição standard brasileira das obras psicológicas completas de Sigmund Freud (J. Salomão, trad., vol. 14, pp. 85-119). Rio de Janeiro: Imago. (Trabalho original publicado em 1914)

Lacan, J. (1998). Escritos (V. Ribeiro, trad.). Rio de Janeiro: Jorge Zahar.

Maggi, N. R. (2002). Por que as crianças resistem às leis? Ciências \& Letras, 32, 105115.

(2005). A fratura da função paterna e o processo de simbolização: um estudo com crianças de periferia urbana em fase de escolaridade inicial. Tese de doutorado, Programa de Pós-Graduação em Educação, Universidade Federal do Rio Grande do Sul.

Nasio, J. D (1991). Lições sobre os 7 conceitos cruciais da psicanálise (V. Ribeiro, trad.). (2a ed.). Rio de Janeiro: Jorge Zahar.
Ogden, T. H. (1995). Sobre o espaço potencial. In P. L. Giovacchini, Táticas e técnicas psicanaliticas (J. O. de Aguiar Abreu, trad.). Porto Alegre, RS: Artes Médicas.

Winnicott, D. W. (1975a). A localização da experiência cultural. In D. W. Winnicott J. O. de Aguiar Abreu \& V. Nobre, trad.), O brincar e a realidade (pp. 133-143). Rio de Janeiro: Imago. (Trabalho original publicado em 1967) . (1975b). O lugar em que vivemos. In D. W. Winnicott (J. O. de Aguiar Abreu \& V. Nobre, trad.), O brincar e a realidade (pp. 145-152). Rio de Janeiro: Imago. . (1975c). Conceitos contemporâneos de desenvolvimento adolescente e suas implicações para a educação superior. In D. W. Winnicott (J. O. de Aguiar Abreu \& V. Nobre, trad.), O brincar e a realidade (pp. 187-202). Rio de Janeiro: Imago. (Trabalho original publicado em 1968)

(1982a). Da dependência à independência no desenvolvimento do indivíduo. In D. W. Winnicott (I. C. S. Ortiz, trad.), $O$ ambiente e os processos de maturação (pp. 79-87). Porto Alegre, RS: Artes Médicas. (Trabalho original publicado em 1963)

(1982b). Teoria do relacionamento paterno-infantil. In D. W. Winnicott (I. C. S. Ortiz, trad.), O ambiente e os processos de maturação (pp. 38-54). Porto Alegre, RS: Artes Médicas, 1982. (Trabalho original publicado em 1960)

(1982c). Distorção do ego em termos de falso e verdadeiro "self". In D. W. Winnicott (I. C. S. Ortiz, trad.), O ambiente e os processos de maturação (pp. 128139). Porto Alegre, RS: Artes Médicas. (Trabalho original publicado em 1960). (1990). Natureza bumana (D. L. Bogomoletz, trad.). Rio de Janeiro: Imago. (Trabalho original publicado em 1988)

(1993). Objetos transicionais e fenômenos transicionais. In D. W. Winnicott (J. Russo, trad.), Textos selecionados: 
Da pediatria à psicanálise (pp. 389-408). Rio de Janeiro: Francisco Alves. (Trabalho original publicado em 1951)

. (1994). Notas sobre o brinquedo.

In C. Winnicott et al. (J. O. de Aguiar Abreu, trad.), Explorações psicanalíticas (pp. 49-52). Porto Alegre, RS: Artes Médicas. . (1999). A tendência anti-social. In D. W. Winnicott (A. Cabral, trad.), Privação e delinquiência (pp. 135-147). São Paulo: Martins Fontes. (Trabalho original publicado em 1956)

\section{NOTAS}

${ }^{1}$ Pesquisa realizada para a tese de doutorado intitulada "A fratura da função paterna e o processo de simbolização: um estudo com crianças de periferia urbana em fase de escolaridade inicial". Programa de Pós-Graduação em Educação. Porto Alegre: UFRGS, 2005.

${ }^{2}$ Espaço potencial é o termo geral que Winnicott usou para referir-se a uma área do experienciar que se localiza entre o mundo interno e a realidade psíquica externa. Esse é o espaço em que a criatividade se torna possível. Winnicott declara que é dentro do espaço potencial que os símbolos se originam.

3 "O termo holding é utilizado para significar não apenas o segurar físico de um lactente, mas também a provisão ambiental total anterior ao conceito de viver com. Em outras palavras, se refere à relação espacial ou em três dimensões com o fator tempo gradualmente adicionado. Isso se superpõe, mas na verdade se inicia antes das experiências instintivas que com o tempo determinaram as relações objetais. Inclui a elaboração de experiências que são inerentes à existência, tais como o completar (e portanto o não-completar) de processos, que de fora podem parecer puramente fisiológicos, mas que fazem parte da psicologia da criança e ocorrem em um campo psicológico complexo, determinados pela percepção e pela empatia da mãe". (Winnicott, 1982b, p. 44).

nrmaggi@portoweb.com.br

Recebido em dezembro/2006.

Aceito em março/2007. 